\title{
Effect of stocking rate and calving date on dry matter intake, milk production, body weight, and body condition score in spring-calving, grass-fed dairy cows
}

\author{
J. McCarthy, ${ }^{\star} \dagger$ B. McCarthy, ${ }^{*}$ B. Horan, ${ }^{* 1}$ K. M. Pierce, $\dagger$ N. Galvin, ${ }^{\star}$ A. Brennan, ${ }^{*}$ and L. Delaby尹 \\ ${ }^{*}$ Animal and Grassland Research and Innovation Centre, Teagasc Moorepark, Fermoy, Co. Cork, Ireland \\ †School of Agriculture, Food Science and Veterinary Medicine, University College Dublin, Belfield, Dublin 4, Ireland \\ †INRA, AgroCampus Ouest, UMR 1348, Physiologie, Environnement et Génétique pour l'Animal et les Systèmes d'Elevage, \\ F-35590 Saint-Gilles, France
}

\begin{abstract}
The primary objective of the study was to quantify the effect of stocking rate (SR) and calving date (CD) on milk production, dry matter intake (DMI), energy balance (EB), and milk production efficiency over 4 consecutive years (2009 to 2012). Two groups of Holstein-Friesian dairy cows with different mean CD were established from within the existing research herd at Moorepark (Teagasc, Ireland). Animals were assigned to either an early calving (mean CD February 14) treatment or a late calving (mean CD March 2) treatment. Animals within each CD treatment were randomly allocated to 1 of 3 whole-farm SR treatments: low (LSR; 2.51 cows/ha), medium (MSR; 2.92 cows/ha), and high (HSR; 3.28 cows/ha), and animals remained on the same farmlet for the duration of the study. Individual animal DMI was estimated 3 times per year at grass using the n-alkane technique in March (spring), May (summer), and September (autumn), corresponding to, on average, 45,132 , and $258 \mathrm{~d}$ in milk, respectively. A total of 138 spring-calving dairy cows were used during each year of the study. The effects of SR, CD, season, and their interaction were studied using mixed models. Individual animal milk production, body weight, body condition score, and the efficiency of milk production were significantly decreased as SR increased due to a reduction in herbage availability. The existence of $\mathrm{CD}$ $\times \mathrm{SR} \times$ season interactions for production, DMI, and $\mathrm{EB}$ indicate that delaying the herd mean $\mathrm{CD}$ can be an effective strategy to minimize the reduction in animal performance, particularly in spring at higher SR. This study further confirms the benefits of a new approach to the evaluation of herbage allowance known as the individual herbage allowance, which encompasses the 3 main factors restricting DMI in rotational grazing;
\end{abstract}

Received September 4, 2013.

Accepted November 23, 2013

${ }^{1}$ Corresponding author: brendan.horan@teagasc.ie namely, the average daily herbage allowance of the group, the intake capacity of the individual animal within the group, and the relative intake capacity of the animal within the competing herd.

Key words: stocking rate, calving date, dry matter intake, feed efficiency

\section{INTRODUCTION}

The imminent abolition of European Union (EU) milk quotas in 2015 creates exciting and challenging opportunities for Ireland's grass-based dairy industry. The medium- to long-term outlook for efficient, grassbased milk production is positive because of lower costs of production associated with grazed grass systems (Dillon et al., 2008), and recent studies evaluating the potential effect of EU milk quota abolition indicate that milk production in Ireland could increase by between 30 and 50\% post-quotas (Lips and Reider, 2005; DAFM, 2010). The realization of increased overall milk production within Irish grazing systems will necessitate increased operational scale and improved production efficiency on existing dairy farms. Productivity within such systems depends on achieving a balance between the competing objectives of high individual animal grass DM and milk production conversion efficiency and maximizing grass production, quality, and utilization (Penno et al., 1996; Peyraud et al., 1996; Prendiville et al., 2011).

Individual animal intake at grazing and milk production efficiency is governed by multiple factors including animal genotype (Horan et al., 2005), grazing stocking rate (SR) and grazing intensity (McCarthy et al., 2013b), herd mean calving date (CD) and calving rate (Dillon et al., 1995; Garcia and Holmes, 2005), and feed allocation rate and quality (Dalley et al., 1999; Peyraud et al., 1996; Stakelum and Dillon, 2007). Stocking rate (cows/ha), defined as the number of animals per unit area of land used during a specified defined period of time (Allen et al., 2011), is widely acknowledged as the main driver of productivity from grazing systems 
(Hoden et al., 1991; Macdonald et al., 2008; Baudracco et al., 2010). A recent review of SR experiments for which no additional supplement was fed as the SR increased reported a 0.20 increase in milk production per hectare arising from an increase in SR of 1 cow/ha (McCarthy et al., 2011). Increasing SR is usually associated with an increase in grazing severity, and many studies have attributed the increased productivity of higher SR systems to an improvement in herbage utilization (McMeekan and Walsh, 1963; Hoden et al., 1991; Macdonald et al., 2008). However, Horan et al. (2004) and Leaver (1985) observed a significant reduction in grass DMI at higher SR because of a reduction in daily herbage allowance (DHA; kg of DM offered/cow per day; Greenhalgh et al., 1966) where strategies were imposed to increase milk production per hectare and improve sward quality. In contrast, other studies have indicated that maximum grass DMI is reached at high DHA (27 to $33 \mathrm{~kg}$ of DM/ cow per day above $4 \mathrm{~cm}$; Leaver, 1985; Peyraud et al., 1996), which are unattainable at higher SR where feed supply is restricted (Macdonald et al., 2008).

In addition to SR, CD is an important determinant of milk production and feed utilization through its effect on the alignment between feed demand and supply. Altering the mean $\mathrm{CD}$ of the herd may have a role in reducing the reliance of grass-based farm systems on purchased feeds, particularly at higher SR. However, few studies have attempted to quantify the effect of mean CD in spring on DMI or elucidate any potential interactions with SR. Dillon et al. (1995) observed that delaying calving until March achieved a better alignment of dairy herd requirements and grass growth, increased milk production from grazed grass, reduced the requirement for purchased supplements, and achieved a greater efficiency of energy utilization particularly at higher SR.

In a post-quota scenario, where land availability is the greatest limitation to milk production, both McCarthy et al. (2007) and Patton et al. (2012) concluded that Irish dairy farms will need to increase overall farm SR from the current mean SR of 1.78 cows/ha (O'Donnell et al., 2008) and mean CD of March 17 (National Farm Survey, 2009) to realize greater levels of milk and milk solids (MS; kg of fat + protein) production per hectare. The objective of this study, therefore, was to evaluate the effect of SR and CD on grass DMI and milk production efficiency of high-genetic-potential Holstein-Friesian (HF) spring-calving dairy cattle over 4 full grazing seasons.

\section{MATERIALS AND METHODS}

This study was undertaken at the Animal and Grassland Research and Innovation Center, Teagasc Moore- park, Ireland $\left(50^{\circ} 7 \mathrm{~N} ; 8^{\circ} 16 \mathrm{~W}\right)$, over a 4 -yr period $(2009$ to 2012). It formed part of a larger study designed to examine the biological and economic effects of alternative SR and CD combinations in the context of the removal of EU milk quotas. A more detailed description of the animals, treatments, and experimental design has been reported previously (McCarthy et al., 2013b). The on-site swards used were predominantly perennial ryegrass (Lolium perenne L.) and had been reseeded over the previous 1 to $9 \mathrm{yr}$.

\section{Feed System Treatments}

The experiment was created in a split-plot design with a $3 \times 2$ factorial arrangement of treatments. The entire experimental area was sub-divided into 18 geographically distinct blocks, each of which comprised 3 paddocks each, to which the whole-plot factor (3 levels of SR) were assigned randomly. Each of these paddocks (within blocks) was then further subdivided into 2 (sub-plots) and the 2 levels of CD were assigned randomly to these sub-plots. The 6 experimental treatments consisted of 3 whole-farm SR $(2.51,2.92$, and 3.28 cows/ha) and 2 mean CD (February 14 and March 2) and were designed to represent alternative springcalving, grass-based milk production models following removal of the EU milk quota. Two groups of high Economic Breeding Index (EBI) HF dairy cattle were established from within the existing Moorepark herd before the commencement of the 2008 breeding season based on parity, BW, EBI, and previous lactation milk production. The average EBI, milk, fertility, calving, beef, maintenance, and health sub-indices of the trial animals were $€ 148$, €59, €78, €27, -€23, €16, and -€3, respectively. In each year of the study, one group was bred to AI over a 13-wk period between April 10 and July 10 to establish the early calving (EC; mean CD February 14) treatment. The second group were bred to AI over a 13-wk period between April 24 and July 24 to establish the late calving (LC; mean CD March 2) treatment. In the $4 \mathrm{yr}$ of the trial, animals were retained within their respective CD and SR treatments by breeding the LC treatment within each SR 2 wk later than the EC treatment. Cows within each CD group were then randomly assigned precalving (based on expected $\mathrm{CD}$, parity, genetic strain, and EBI) to 1 of 3 SR treatments, low (2.51 cows/ha; LSR), medium (2.92 cows/ha; MSR), and high (3.28 cows/ha; HSR). The SR were 16 and $31 \%$ greater in the MSR and HSR treatments than in the LSR treatment. The LSR treatment was designed to allow each animal to express its potential at high herbage allowances of high quality grass and small amounts of concentrates, whereas the aim of the MSR and HSR treatments was to investigate 
the potential to increase animal productivity per hectare by increasing SR and herbage utilization by grazing to lower postgrazing residual sward heights (PGRSH).

\section{Grazing Management}

Cows were turned out to grass by day and night, as they calved, from early February in the 4 yr of the study. Concentrate supplementation was similar for each SR (400 kg of DM/cow); however, less concentrate was fed to the LC groups (425 vs. $376 \mathrm{~kg}$ of DM/cow for EC compared with LC) according to the supplementation plan. The concentrate supplementation plan for all treatments was as follows: supplementation commenced at $4 \mathrm{~kg} / \mathrm{d}$ postcalving and was reduced and removed totally only when herbage supply exceeded animal demand for all treatments (usually in mid-March). The LC cows received concentrate for a shorter period than the EC cows due to their later mean CD. Concentrate and additional forage supplementation (in the form of baled silage) were used on several occasions during the main grazing season of each of the $4 \mathrm{yr}$ when grass supply was reduced. Concentrate supplement was only used when a feed deficit occurred, because of reductions in grass growth, for all SR treatments and at a similar rate per cow (up to a maximum of $5 \mathrm{~kg} /$ cow per day) in all treatments on those occasions. When feed deficits arose, for individual SR treatments (e.g., if the feed deficit could not be filled by concentrate alone or a feed deficit occurred only in the higher SR treatments), conserved forage produced within each treatment was used to supplement the feed supply. The ingredient composition of the concentrate feed was barley $25 \%$, corn gluten $26 \%$, beet pulp $35 \%$, soybean meal $11 \%$, and minerals plus vitamins $3 \%$. Mean concentrate quality was $157 \mathrm{~g} / \mathrm{kg} \mathrm{CP}, 270 \mathrm{~g} / \mathrm{kg} \mathrm{NDF}, 80.9 \mathrm{~g} / \mathrm{kg}$ crude fiber, and $96.2 \mathrm{~g} / \mathrm{kg}$ ash. Mean silage quality was $151 \mathrm{~g} /$ $\mathrm{kg} \mathrm{CP}, 553 \mathrm{~g} / \mathrm{kg} \mathrm{NDF}, 378 \mathrm{~g} / \mathrm{kg} \mathrm{ADF}$, and $94 \mathrm{~g} / \mathrm{kg}$ ash.

A rotational-stocking system was practiced, and on-off grazing (Kennedy et al., 2009) was used as a management tool to facilitate grazing during periods of inclement weather. Grazing management was accomplished by weekly monitoring of farm grass cover within each SR treatment. Calving date treatments within each SR were grazed in sub-paddocks adjacent to each other and were managed similarly (i.e., similar target pregrazing yield, PGRSH, and residency time in paddocks). The residency time within each paddock, ranging from 1.5 to $2.5 \mathrm{~d} /$ sub-paddock, was determined by targeting PGRSH of 4.5 to $5.0,4.0$ to 4.5 , and 3.5 to $4.0 \mathrm{~cm}$ for LSR, MSR, and HSR, respectively, and each group was moved to the next paddock once this target was reached. The 4.0 to $4.5 \mathrm{~cm}$ height was picked as the PGRSH for the MSR as this had been used at similar
SR previously (McEvoy et al., 2009; Wims et al., 2010). The PGRSH for the LSR and the HSR were increments above and below 4.0 to $4.5 \mathrm{~cm}$. Weekly grazing management during the first rotation (February 1 to April 1) was based on allocating an equal and increasing proportion of each farmlet to each treatment up to the start of rotation 2. All silage was conserved in bales $(259 \mathrm{~kg}$ of $\mathrm{DM} \pm 44.7)$. A sample of herbage was taken before baling for DM determination, and bales were weighed from each paddock to give an estimate of the amount of feed conserved from each paddock (Macdonald et al., 2008). No mechanical topping of the swards took place for the duration of the experiment.

\section{Animal Measurements}

Cows were milked twice daily throughout lactation across the $4 \mathrm{yr}$ of the study. Milking took place at 0700 and $1530 \mathrm{~h}$ daily. Weekly milk production was derived from individual cow milk yield $(\mathrm{kg})$ recorded at each milking (Dairymaster, Causeway, Co. Kerry, Ireland). Milk fat, protein, and lactose concentrations were determined in successive p.m. and a.m. samples of milk each week using Milkoscan 203 (Foss Electric, Hillerød, Denmark) and weekly SCM (Tyrrell and Reid, 1965), fat, protein, lactose, and MS yields were calculated. Individual animal BW was recorded weekly upon exit from the milking parlor using an electronic scale (TruTest Ltd., Auckland, New Zealand) calibrated weekly against known weights. Animal BCS was measured every $4 \mathrm{wk}$ throughout the study on a 1 to 5 scale (1 $=$ thin, 5 = fat) in increments of 0.25 as outlined by Edmonson et al. (1989). Body condition was assigned by one individual throughout the study.

Measurements of individual cow DMI were estimated using the n-alkane technique (Mayes et al., 1986) as modified by Dillon and Stakelum (1989). Individual DMI were measured on 3 occasions during the grazing seasons (S) of 2009, 2010, 2011, and 2012 corresponding with the early spring (February; DIM $=45$ ), summer (May; DIM = 132), and autumn (September; DIM $=258$ ). Season encompasses both the effect of the season of year and the effect of lactation stage. Observations on DMI across animals ranged from 16 to 288 DIM. Cows were dosed twice daily after milking with paper bungs containing $500 \mathrm{mg}$ of C32-alkane (n-dotriacontane) over a 12-d period. On d 7 to 12 , fecal grab samples from each cow were collected. These were subsequently bulked per cow to give 1 sample per cow per intake period and sub-sampled for analysis. Selected herbage samples were also taken to grazing height following close observation of the grazing of the cows. The ratio of herbage C33-alkane (tritriacontane) to dosed C32-alkane was used to estimate DMI. 
The intake capacity of individual cows (IndIC) was calculated using the equations of Faverdin et al. (2011) based on animal characteristics at the time of intake measurement. Briefly, required inputs to calculate intake capacity are actual milk yield, parity (primiparous or multiparous), BW, BCS, age, stage of lactation, stage of gestation, and potential peak milk production. Subsequently, the herd average intake capacity (HerdAvgIC) was calculated as the average DHA weighed according to the ratio of AvgHerdIC to IndIC for all animals within the group.

Measures of gross milk production efficiency were calculated according to the net energy system (O'Mara, 2000), where 1 unite fourragère lait (UFL) of energy is defined as the net energy content of $1 \mathrm{~kg}$ of standard barley for milk production; that is, 1,700 kcal. The measures of milk production efficiency calculated were grams of MS per kilogram of DMI, kilograms of MS per $100 \mathrm{~kg}$ of BW, and total DMI per $100 \mathrm{~kg}$ of BW. In addition, net energetic efficiency (measured as the amount of MS produced per 1 UFL of feed intake) and net feed efficiency (which represents the MS produced per 1 UFL available for milk production after adjusting the energy requirements for maintenance; UFL NEI) were also calculated, similar to Lopez-Villalobos et al. (2008) and Prendiville et al. (2009).

\section{Grass Measurements}

Grazing data were collected on all paddocks during each grazing rotation in all $4 \mathrm{yr}$. Pregrazing herbage mass ( $>3.5 \mathrm{~cm}$ horizon) was determined before grazing on each paddock for each of the 6 systems by harvesting 2 strips $(1.2 \times 10 \mathrm{~m})$ of grass with an Agria autoscythe (Etesia UK Ltd., Warwick, UK). All mown herbage from each strip was collected and weighed, and a $0.1-\mathrm{kg}$ (fresh weight) subsample was taken and dried for $16 \mathrm{~h}$ at $90^{\circ} \mathrm{C}$ for $\mathrm{DM}$ determination. Ten compressed sward height (CSH) measurements were recorded before and after harvesting on each cut strip using a folding grass plate meter with a steel plate (Jenquip, Feilding, New Zealand). Based on the aforementioned measurements, sward density was calculated as follows (Delaby and Peyraud, 1998): Sward density $=$ herbage mass $(\mathrm{kg}$ of $\mathrm{DM} / \mathrm{ha}) /$ (precutting - postcutting $\mathrm{CSH}) ; \mathrm{kg}$ of $\mathrm{DM} / \mathrm{cm}$. Pregrazing and postgrazing CSH were also determined on each paddock before and after grazing by taking between 30 and 50 measurements across the diagonal of the paddock. The average paddock pregrazing herbage mass above a cutting height of $3.5 \mathrm{~cm}$ was then calculated according to the following formula: Pregrazing herbage mass $=[$ pregrazing CSH $(\mathrm{cm})-3.5 \mathrm{~cm}] \times$ sward den- sity; $\mathrm{kg}$ of $\mathrm{DM} / \mathrm{cm}$. Average DHA at each grazing was also calculated using the formula: (Pregrazing herbage mass; $\mathrm{kg}$ of $\mathrm{DM} / \mathrm{ha} \times$ daily grazing area allowance (ha/cow). Subsequently, and similar to the methods of Delagarde et al. (2011), a new individual animal measure of herbage availability (individual herbage allowance; IndDHA) was calculated based on the proportional intake capacity of the individual animal within a group in the same paddock with the same average DHA. This new measure of herbage allowance assumes that the herbage intake of a cow (or group of cows) within a herd depends on the herbage intake level of the other cows, as the limited area per cow per day leads to competition for feed. The IndDHA is calculated based on the equation IndDHA $=(\mathrm{DHA} /$ HerdAvgIC) $\times$ IndIC $(\mathrm{kg}$ of $\mathrm{DM} /$ cow per day $)$. The relationship between IndDHA and DHA, HerdAvgIC, and IndIC are highlighted in Figure 1.

\section{Statistical Analysis}

The effect of SR, CD, S, and year on mean daily milk production, grass DMI, total DMI, and feed efficiency during each DMI measurement period across the 4 -yr study were determined using mixed models (Proc Mixed, SAS Institute, 2006). Initial models included the effects of SR, CD, S, parity, year, and their interactions. Stocking rate, CD, S, and parity were included as fixed effects. Nonsignificant effects $(P>0.05)$ were removed from the model by backward elimination. Year was included as a repeated effect with a first-order autoregressive covariance structure with homogeneous variances assumed among records within cow-year.

A subsequent analysis was undertaken to develop prediction equations for grass DMI based on multiple linear regression analysis incorporating grazing (DHA and IndDHA), animal characteristic (BW, milk production potential, parity), year, and season effects. This analysis was carried out using the general linear model procedure of SAS Institute (2006). If the calculated $F$ statistic was $P<0.05$ for an independent variable, then that variable was retained in the model. The outcome of the analysis was to construct 3 final models that represented the influence of animal and herbage allowance characteristics on grass DMI.

\section{RESULTS}

An overview of the multi-year overall lactation milk production, reproductive performance, and annual herbage production and utilization from this study has been reported previously (McCarthy et al., 2012, 2013a,b). 
a)

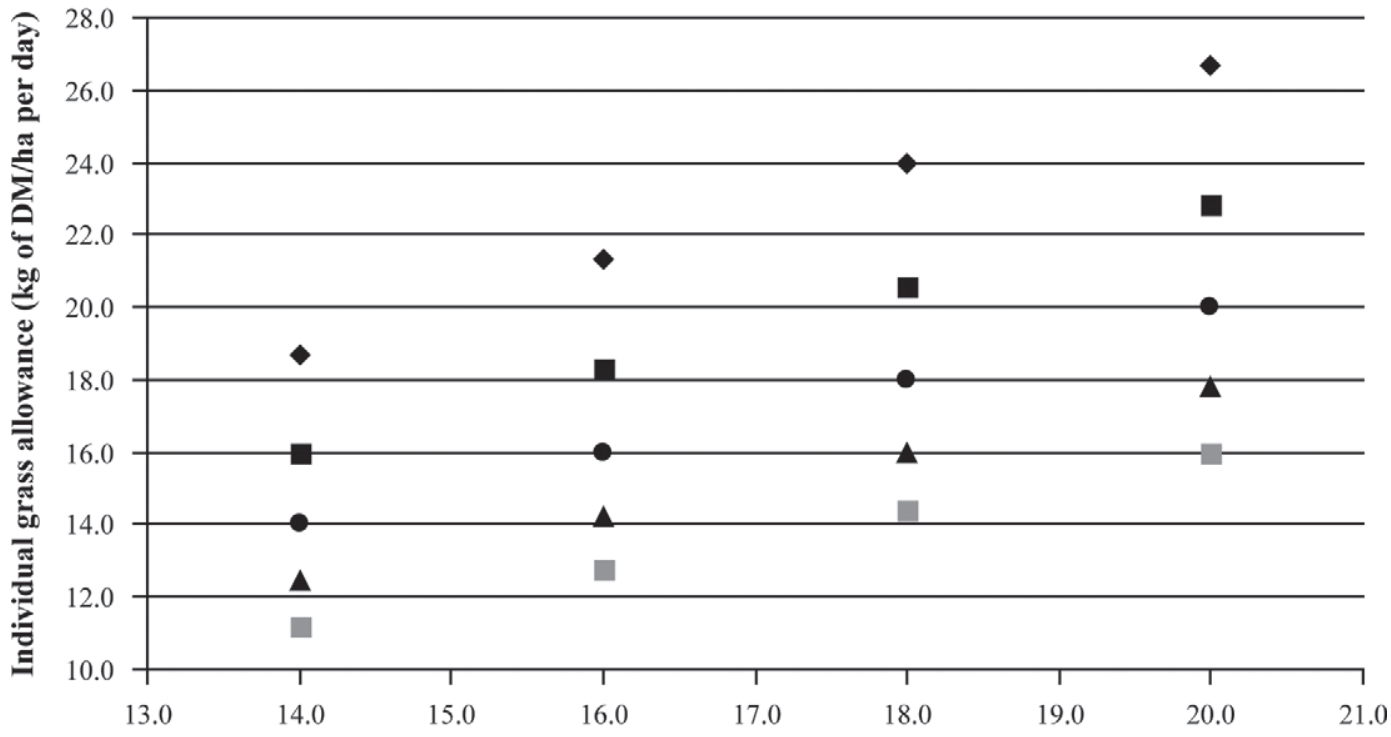

b)

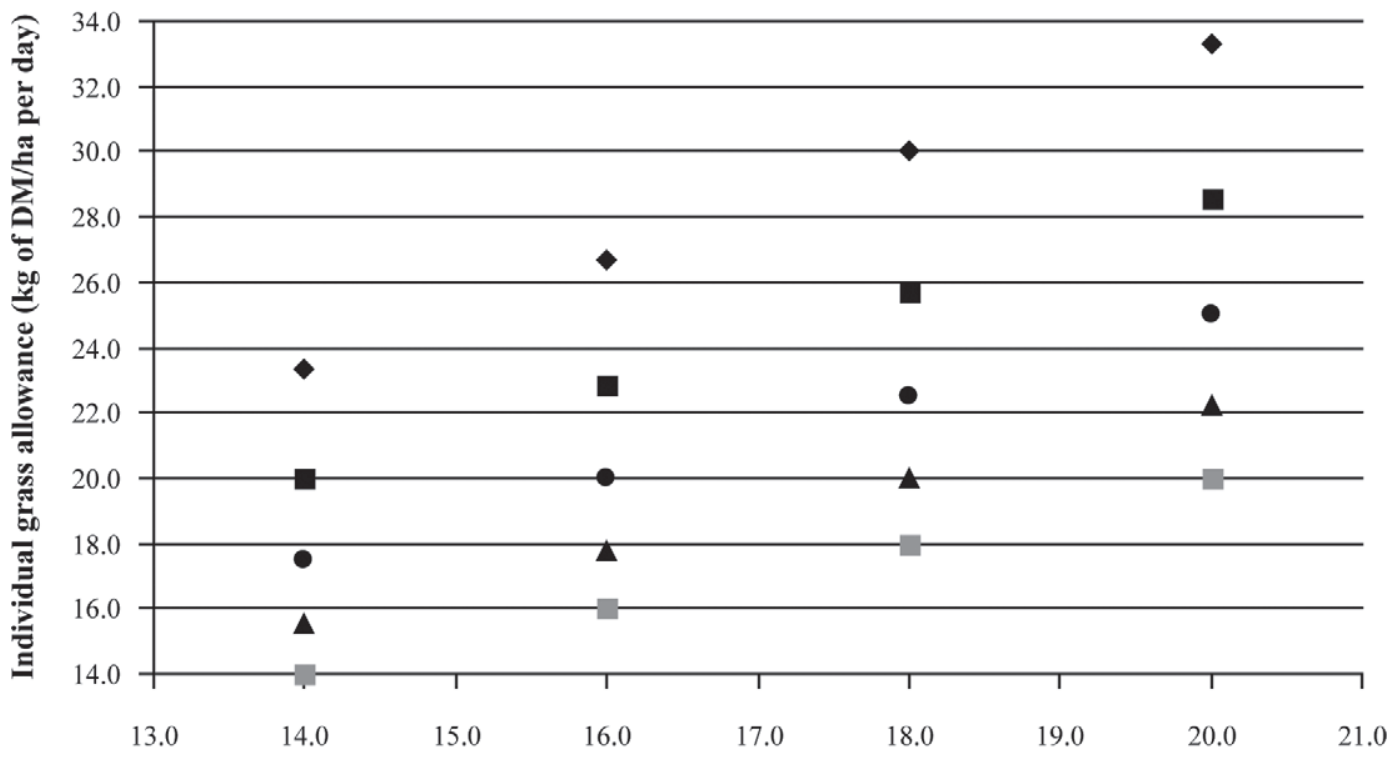

Individual intake capacity (kg of DM/cow per day)

Figure 1. An illustration of the effect of individual animal intake capacity (x-axis) on individual animal grass allowance (IndDHA; y-axis) according to different level of herd average intake capacity: $12(\bullet), 14(\mathbf{\square}), 16(\boldsymbol{\bullet}), 18(\boldsymbol{\Lambda})$, and $20(\square) \mathrm{kg}$ of DM/cow per day. (a) Average daily herbage allowance of $16 \mathrm{~kg}$ of DM/cow per day; (b) average daily herbage allowance of $20 \mathrm{~kg}$ of DM/cow per day.

\section{Effects of SR and CD on DHA and Sward Characteristics}

The effects of SR and CD on sward characteristics and herbage allowance across all measurement periods are presented in Table 1. Stocking rate had a significant $(P<0.001)$ effect on all variables with the exception of pregrazing herbage mass and sward $\mathrm{CP}$ content. The
LSR treatment had the highest average PGRSH (4.2 $\mathrm{cm})$, the greatest average DHA $(17.4 \mathrm{~kg} /$ cow per day), and the lowest average sward OM digestibility (OMD; $77.3 \%$ ). In contrast, the HSR group achieved the lowest average PGRSH $(3.3 \mathrm{~cm})$ and average DHA (13.1 $\mathrm{kg} /$ cow per day) and the greatest sward OMD content (79.4\%), whereas the MSR group was intermediate for all variables $(3.8 \mathrm{~cm}, 15.7 \mathrm{~kg} / \mathrm{cow}$ per day, and $77.9 \%$, 
respectively). Neither CD nor the interaction of CD and SR had any effect on sward characteristics, although the effect of CD on average DHA approached significance $(P=0.14)$ because of the comparably greater DHA of the LC treatments (14.9 vs. $15.8 \mathrm{~kg} / \mathrm{cow}$ per day). Season had a significant effect on all sward characteristics and DHA. Pregrazing herbage mass and PGRSH were lower in spring $(3.2 \mathrm{~cm})$ compared with summer and autumn (4.0 and $3.9 \mathrm{~cm}$, respectively). Average DHA was lowest in spring (13.3 kg/cow per day) compared with both summer and autumn (16.9 and $15.9 \mathrm{~kg} / \mathrm{cow}$ per day, respectively). Sward CP content and OMD were greatest in spring $(230 \mathrm{~g} / \mathrm{kg}$ and $82.0 \%$, respectively). Although sward CP content was similar during summer and autumn (204 and $206 \mathrm{~g} / \mathrm{kg}$, respectively), sward OMD content continued to decline between summer and autumn (79.2 and 73.3\%, respectively).

\section{Effects of SR and CD on Milk Production, $B W$, and $B C S$}

The effects of SR and CD on milk production, BW, and BCS during the intake measurement periods are described in Table 2. We observed a significant effect of SR, CD (with the exception of fat yield, BW, and BCS), and S (with the exception of BCS) on all milk production variables during the intake measurement periods. No interactions were observed between CD and SR or between CD, SR, and S for any of the milk production variables investigated. The LSR treatment achieved the greatest daily milk $(21.6 \mathrm{~kg} / \mathrm{cow}$ per day), fat $(0.89 \mathrm{~kg} /$ cow per day $)$, protein $(0.78 \mathrm{~kg} /$ cow per day), and lactose $(1.02 \mathrm{~kg} /$ cow per day) yields, whereas HSR was lowest $(19.3,0.83,0.68$, and $0.90 \mathrm{~kg} / \mathrm{cow}$ per day, respectively) and MSR was intermediate (20.2, $0.86,0.72$, and $0.94 \mathrm{~kg} / \mathrm{cow}$ per day, respectively). In addition, we observed a significant effect of SR on BW and BCS during the measurement periods. The BW and BCS of the LSR was greatest $(492 \mathrm{~kg}$ and 2.95 BCS, respectively; $P<0.001$ ), and although BCS did not differ between MSR and HSR (2.92 and 2.90 BCS, respectively), MSR achieved an intermediate BW (485 $\mathrm{kg}$ ), whereas that of HSR was lowest $(477 \mathrm{~kg} ; P<$ 0.001). Although having little effect on BW and BCS, delaying mean $\mathrm{CD}$ resulted in increased daily milk (20.7 kg/cow per day), protein $(0.74 \mathrm{~kg} /$ cow per day), lactose $(0.97 \mathrm{~kg} / \mathrm{cow}$ per day), SCM $(20.3 \mathrm{~kg} /$ cow per day), and MS (1.60 kg/cow per day) yields compared with the EC treatment (19.98, 0.71, 0.94, 19.7, and 1.56 $\mathrm{kg} /$ cow per day, respectively).

Season had a significant $(P<0.001)$ effect on all milk production parameters. In spring, daily milk $(24.1 \mathrm{~kg} /$ cow per day), MS $(1.82 \mathrm{~kg} / \mathrm{cow}$ per day), SCM $(23.2$ $\mathrm{kg} /$ cow per day), fat $(0.99 \mathrm{~kg} / \mathrm{cow}$ per day $)$, protein
$(0.82 \mathrm{~kg} / \mathrm{cow}$ per day), and lactose $(1.14 \mathrm{~kg} / \mathrm{cow}$ per day) yields were greatest, compared with autumn, when yields were lowest $(14.3,1.25,15.2,0.68,0.57$, and $0.64 \mathrm{~kg} /$ cow per day, respectively), and summer, when yields were intermediate $(22.7,1.69,21.6,0.91$, 0.78 , and $1.08 \mathrm{~kg} / \mathrm{cow}$ per day, respectively). Season also had a significant effect $(P<0.001)$ on BW and approached significance for BCS $(P=0.14)$. Body weight and BCS were greatest during autumn $(510 \mathrm{~kg}$ and 2.94 BCS), lowest in spring (460 kg and $2.90 \mathrm{BCS}$ ), and intermediate in summer (484 kg and $2.92 \mathrm{BCS}$ ).

\section{Effect of SR, CD, and S on Grass and Total DMI and Milk Production Efficiency}

The effects of SR, CD, and S on grass and total DMI are presented in Table 3. Both SR and S had a significant effect of on all intake variables and we observed significant interactions between $\mathrm{CD} \times \mathrm{SR}$ and $\mathrm{CD} \times$ $\mathrm{SR} \times \mathrm{S}$ within the measurement periods. The LSR treatment achieved the greatest grass $(14.8 \mathrm{~kg} / \mathrm{cow}$ per day), and total $(15.8 \mathrm{~kg} /$ cow per day) DMI compared with HSR, which had the lowest (12.6 and $13.6 \mathrm{~kg} / \mathrm{cow}$ per day, respectively), whereas MSR was intermediate (14.3 and $15.3 \mathrm{~kg} /$ cow per day, respectively). The late CD treatment tended to achieve a higher grass (14.1 $\mathrm{kg} /$ cow per day) and total (15.1 kg/cow per day) DMI, compared with the early CD treatment (13.9 and 14.9 $\mathrm{kg} /$ cow per day). Grass and total DMI was greatest in summer (15.0 and $15.9 \mathrm{~kg} /$ cow per day, respectively), lowest in spring (13.1 and $13.8 \mathrm{~kg} / \mathrm{cow}$ per day, respectively), and intermediate in autumn (13.9 and $15.2 \mathrm{~kg} /$ cow per day, respectively). We observed a significant SR $\times$ CD interaction for all daily intake variables estimated. Compared with the late CD group, the grass DMI of the HSR treatment in the early CD group was reduced by $0.8 \mathrm{~kg}$ of DM, compared with 0.0 and $0.1 \mathrm{~kg}$ of DM for the LSR and MSR treatments, respectively. The interaction of $\mathrm{SR} \times \mathrm{CD} \times \mathrm{S}$ was also significant for total DMI and approached significance for grass DMI because of the comparably higher intakes of the late CD higher SR treatments (MSR and HSR) during spring and summer.

The effects of SR, CD, and S on energy intake and partitioning and milk production efficiency are presented in Table 3. The LSR treatment achieved a higher $(P<0.001)$ estimated total energy intake $(16.5$ $\mathrm{UFL} / \mathrm{d})$ and daily EB $(+1.5 \mathrm{UFL} / \mathrm{d})$ compared with HSR (14.6 and +0.7 UFL/d), whereas MSR was intermediate for energy intake (16.0 UFL/d) and achieved the greatest estimated average EB $(+1.7 \mathrm{UFL} / \mathrm{d})$. As for grass and total DMI, we found significant SR $\times$ $\mathrm{CD}$ and $\mathrm{SR} \times \mathrm{CD} \times \mathrm{S}$ interactions for estimated total daily energy intake and EB variables. Across all seasons 
Table 1. Effect of stocking rate (low, medium, or high), calving date (early or late), and season on grazing characteristics, grass allowance and quality during the intake measurement periods

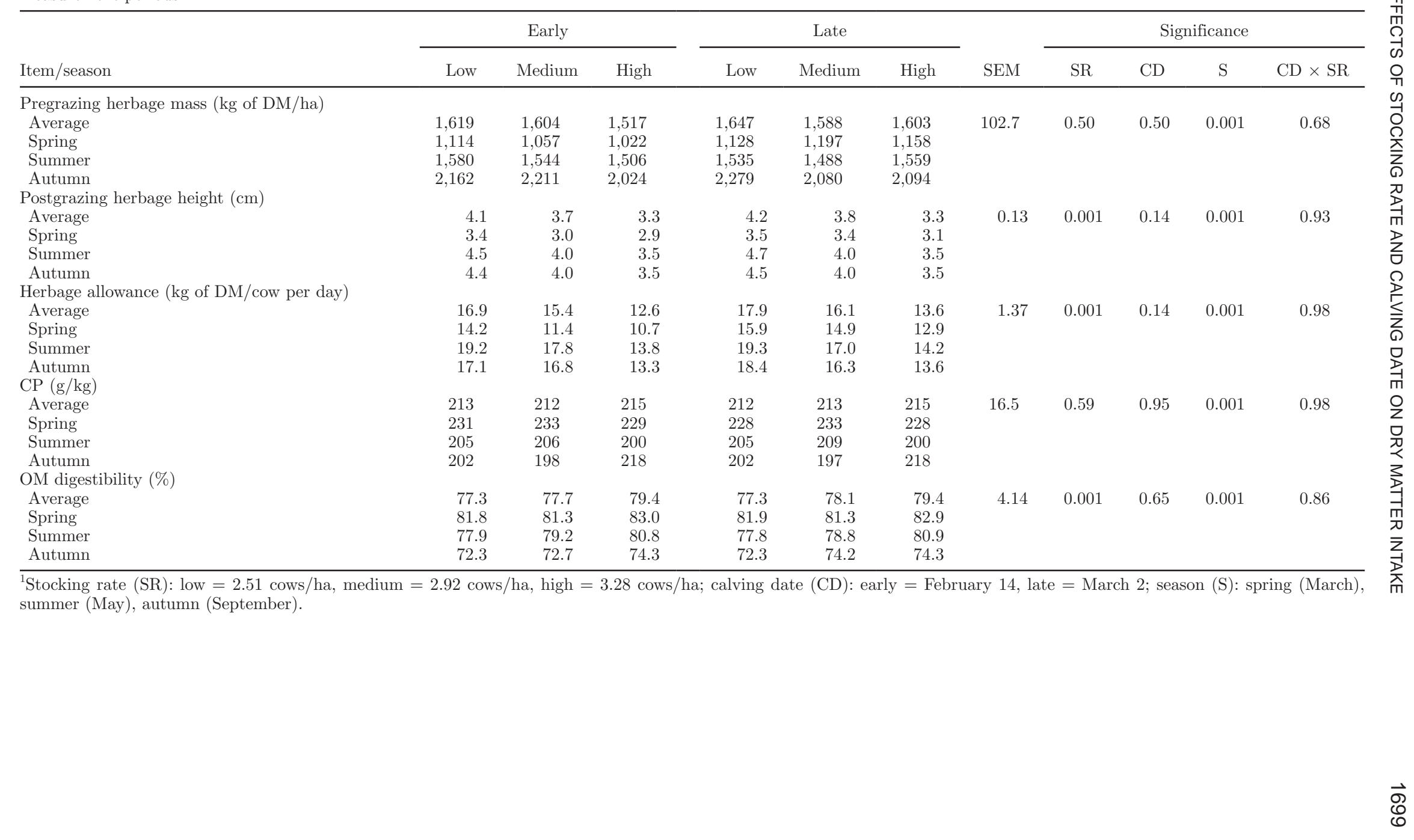


Table 2. Effect of stocking rate (low, medium, or high) and calving date group (early or late) on milk production, BW, and BCS during the intake measurement periods ${ }^{1}$

\begin{tabular}{|c|c|c|c|c|c|c|c|c|c|c|c|c|}
\hline $\begin{array}{l}\text { Milk production } \\
(\mathrm{kg} / \text { cow per } \mathrm{d})\end{array}$ & \multicolumn{3}{|c|}{ Early } & \multicolumn{3}{|c|}{ Late } & SEM & \multicolumn{5}{|c|}{ Significance } \\
\hline Milk & 21.2 & 19.9 & 18.8 & 21.9 & 20.4 & 19.8 & 0.29 & 0.001 & 0.002 & 0.001 & 0.59 & 0.78 \\
\hline Protein & 0.76 & 0.71 & 0.66 & 0.79 & 0.72 & 0.70 & 0.010 & 0.001 & 0.002 & 0.001 & 0.25 & 0.41 \\
\hline Lactose & 1.01 & 0.92 & 0.88 & 1.03 & 0.96 & 0.93 & 0.015 & 0.001 & 0.003 & 0.001 & 0.62 & 0.59 \\
\hline SCM & 20.8 & 19.7 & 18.7 & 21.4 & 19.9 & 19.4 & 0.29 & 0.001 & 0.02 & 0.001 & 0.60 & 0.33 \\
\hline $\mathrm{BCS}$ & 2.95 & 2.89 & 2.91 & 2.95 & 2.94 & 2.88 & 0.021 & 0.06 & 0.67 & 0.14 & 0.13 & 0.61 \\
\hline
\end{tabular}

${ }^{1}$ Stocking rate $(\mathrm{SR}):$ low $=2.51 \mathrm{cows} /$ ha, medium $=2.92 \mathrm{cows} /$ ha, high $=3.28 \mathrm{cows} /$ ha; calving date $(\mathrm{CD})$ : early $=$ February 14, late $=$ March 2; season (S): spring (March), summer (May), autumn (September).

and compared with the early CD group, the total energy intake and daily EB of the HSR treatment in the late CD group increased (by +0.7 and $+0.4 \mathrm{UFL} / \mathrm{d}$, respectively) compared with the MSR $(+0.1$ and +0.2 $\mathrm{UFL} / \mathrm{d}$, respectively) and LSR $(+0.1$ and $+0.3 \mathrm{UFL} / \mathrm{d}$, respectively) treatments. Furthermore, the results indicate that the differential in daily energy intake and EB in favor of the late CD HSR treatment was greatest in spring (1.4 and 0.8 UFL/d, respectively) and least in autumn (0.1 and $0.1 \mathrm{UFL} / \mathrm{d}$, respectively) compared with the early CD HSR treatment. The HSR treatment had the lowest total DMI/100 kg of BW $(P<0.05 ; 2.96$ $\mathrm{kg})$ and produced the least MS per $100 \mathrm{~kg}$ of BW $(P<$ $0.05 ; 0.32 \mathrm{~kg}$ ), compared with LSR, which was greater (3.19 and $0.34 \mathrm{~kg}$, respectively) and with MSR, which was intermediate (3.16 and $0.34 \mathrm{~kg}$, respectively). In contrast, HSR achieved a comparably greater MS yield per UFL of NEI $(0.16 \mathrm{~kg} / \mathrm{UFL})$, compared with both LSR and MSR $(0.15 \mathrm{~kg} / \mathrm{UFL})$. We observed a significant SR $\times$ CD interaction for both total DMI/100 kg of BW and MS per UFL of NEI, which arose due to the comparably greater intake and MS production of the

Table 3. Effect of stocking rate (low, medium, or high), calving date group (early or late), and season on DMI, energy balance, and milk production efficiency ${ }^{1}$

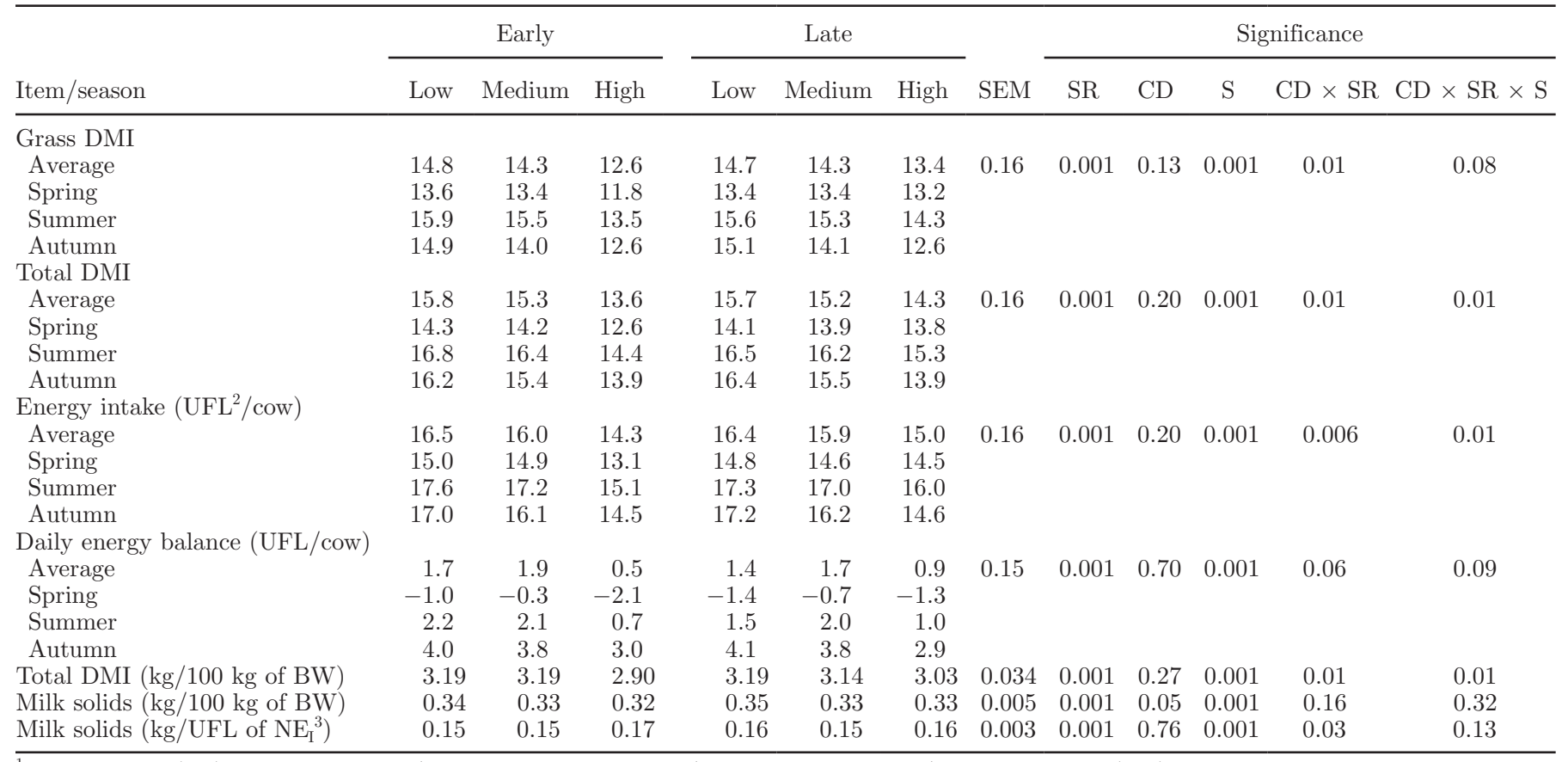

${ }^{1}$ Stocking rate $(\mathrm{SR})$ : low $=2.51 \mathrm{cows} / \mathrm{ha}$, medium $=2.92 \mathrm{cows} / \mathrm{ha}$, high $=3.28 \mathrm{cows} /$ ha; calving date $(\mathrm{CD})$ : early $=$ February 14 , late $=$ March 2 ; season (S): spring (March), summer (May), autumn (September).

${ }^{2}$ Unite fourragère lait, defined as the net energy content of $1 \mathrm{~kg}$ of standard barley for milk production; that is, 1,700 kcal.

${ }^{3}$ Milk solids produced per UFL of net energy intake. 
HSR treatment in the late CD group. In addition, we found a significant $\mathrm{SR} \times \mathrm{CD} \times \mathrm{S}$ interaction for total $\mathrm{DMI} / 100 \mathrm{~kg}$ of $\mathrm{BW}$, which arose due to the comparably greater intake of the HSR treatment in the late CD group during spring.

Season had a significant effect on energy intake, $\mathrm{EB}$, and milk production efficiency. Estimated energy intake and daily EB was lowest in spring (14.5 and $-1.1 \mathrm{UFL} / \mathrm{d}$, respectively), whereas energy intake was greatest in summer and intermediate during autumn (16.7 and 15.9 UFL/d, respectively), and daily EB was greatest in autumn and intermediate during summer (3.6 and 1.6 UFL/d, respectively). Total DMI per 100 $\mathrm{kg}$ of BW was greatest $(P<0.0001)$ in summer $(3.29$ $\mathrm{kg} / \mathrm{d})$ compared with both spring $(3.02 \mathrm{~kg} / \mathrm{d})$ and autumn $(3.00 \mathrm{~kg} / \mathrm{d})$. Both MS/100 kg of BW and MS per UFL of NEI were greatest in spring $(P<0.0001)$, when all animals were in early lactation $(0.39$ and $0.20 \mathrm{~kg}$ of MS, respectively), lowest in autumn $(0.25$ and $0.12 \mathrm{~kg}$ of MS, respectively), and intermediate during summer (0.35 and $0.15 \mathrm{~kg}$ of MS, respectively).

\section{Effect of Grazing and Animal Characteristics on Grass DMI}

The regression equations for the prediction of grass DMI are presented in Table 4. The relationship between average DHA and grass DMI within the current data set is described by equation 1 . The adjusted $R^{2}$ of 0.39 and low root mean square error (RMSE) of 2.35 indicate that average DHA is an important indicator of grass DMI and the results show that a 1-kg increase in DHA is associated with a $0.25-\mathrm{kg}$ increase in grass DMI. When this relationship was supplemented with animal characteristics (BW, parity, milk production potential; equation 2), the accuracy of prediction is improved $\left(\mathrm{R}^{2}\right.$ $=0.52$ ) and the RMSE is reduced to 2.08. In equation 2 , average DHA continues to be an important indicator of grass DMI (1-kg increase in DHA is associated with a $0.28-\mathrm{kg}$ increase in grass $\mathrm{DMI}$ ); parity, potential milk yield, and BW are also influential characteristics. As parity increased from 1 to 2 and from 2 to 3, grass DMI increased by 1.24 and $1.34 \mathrm{~kg} /$ cow per day, respectively. Similarly, an increase in potential milk production of $1 \mathrm{~kg} /$ cow per day and an increase in BW of $100 \mathrm{~kg}$ was associated with $0.05-$ and $1.50-\mathrm{kg}$ increases in grass DMI, respectively. Finally, the relationship between IndHA and grass DMI is described by equation 3 . The adjusted $R^{2}$ of 0.61 and further reduced RMSE of 1.87 indicate that IndHA, together with parity, provides an excellent indicator of grass DMI; the results show that a $1-\mathrm{kg}$ increase in IndHA was associated with a $0.28-\mathrm{kg}$ increase in grass DMI.

\section{DISCUSSION}

Maximum profitability within grazing systems is achieved by maximizing grass growth and grazed grass utilization (Dillon et al., 2008). Previous studies have indicated that this will be achieved where CD and feed demand are synchronized to feed supply at a relatively high SR at the start of the grass-growing season (Holmes et al., 2002; McCarthy et al., 2013b). Experiments using $\mathrm{SR}$ as the main variable are difficult to interpret because of the important effect of experimental decision rules. Similar to Macdonald et al. (2008), and unlike classical SR experiments, the grazing management decision rules used in this experiment attempted to optimize performance within each SR treatment. Previously, Le Du et al. (1979) suggested that measurements of residual sward height in rotational grazing systems could be used as a measure of grazing severity; therefore, different target PGRSH were adopted in this study to allow the SR effects to be imposed homogeneously during the experiment. As a consequence, the results of this study indicate the likely implications of increasing SR in a closed system (i.e., supplementation was not increased as SR increased) when associated with an increase in grazing severity. The current experiment, combining a range of relatively high $\mathrm{SR}$ and relatively early $\mathrm{CD}$

Table 4. Equations derived to explain variation in grass DMI

\begin{tabular}{lccc}
\hline & \multicolumn{3}{c}{ Equation } \\
\cline { 2 - 4 } Item $^{1}$ & 1 & 2 & 3 \\
\hline Origin & 10.46 & 1.49 & 9.80 \\
Parity 1/2/3 & & $-0.86 / 0.38 / 0.48$ & $-1.22 / 0.31 / 0.91$ \\
Average DHA (kg of DM/cow per day) & 0.25 & 0.28 & \\
Potential milk yield (kg/cow per day) & & 0.05 & 0.28 \\
BW (kg) & & 0.015 & 1.87 \\
IndHA (kg of DM/cow per day) & 2.35 & 2.08 & 0.61 \\
Root mean square error & 0.39 & 0.52 & \\
$\mathrm{R}^{2}$ &
\end{tabular}

${ }^{1} \mathrm{DHA}=$ daily herbage allowance; IndHA $=$ individual herbage allowance. 
treatments compared with those used in commercial practice in Ireland, was designed to evaluate the effects of SR and $\mathrm{CD}$ on the likely performance of grazing animals within Irish dairy herds following abolition of the EU milk quota. Although Dillon et al. (1995) previously investigated the effect of increasing SR and altering mean CD, the unbalanced design of that study did not permit the evaluation of potential interactions between SR and CD. Although McCarthy et al. (2013b) previously reported the lactation milk production effects associated with the SR and CD treatments reported here, the current analysis focuses specifically on the DMI effects and associated milk production effects of these treatments during the DMI measurement periods and provides a unique opportunity to validate the approach to IndHA proposed by Institut National de la Recherche Agronomique (INRA) in the Graz'IN model (Delagarde et al., 2011). This study is the first study to investigate the interaction between SR and CD on milk production efficiency, BW, BCS, DMI, and energy partitioning during specific intake measurement periods and over multiple grazing seasons. The LSR treatment represents the control SR and was chosen as the normal SR recommended to commercial Irish producers and used within research trials (Horan et al., 2005), whereas MSR and HSR represent 2 incremental increases in SR. In addition to the effects of SR and CD on DMI and milk production performance during the intake measurement periods reported in this paper, the effects of SR and CD on lactation milk production performance per cow and per hectare, sward productivity, system level feed budgets, and reproductive performance have been reported elsewhere (McCarthy et al., 2012, 2013a,b), using a subset of data from this study.

\section{Effect of SR, CD, and S on DHA, Milk Production, $B W, B C S$, and Grass and Total DMI and Milk Production Efficiency}

Increasing $\mathrm{SR}$ is considered akin to a reduction in DHA (Baudracco et al., 2010; McCarthy et al., 2011) and consequently results in reduced animal intake and milk production compared with lower SR treatments (Leaver, 1985; Dillon, 2006). Although increased concentrate supplementation can be used to arrest the decline in DMI at higher SR (Coleman et al., 2010; Farina et al., 2011), the objective of this analysis was to investigate the effects of increased SR when concentrate supplementation levels are not increased as SR increased. The quantity of herbage allocated to MSR and HSR within this study was reduced to 90 and $75 \%$, respectively, of that allocated to LSR due to the increased grazing severity of MSR and HSR. Similar to increased SR, earlier calving resulted in reduced herb- age availability; consequently, the differential in herbage allowance in favor of LSR was greater in the early CD treatment ( 88 and $82 \%$ of LSR for MSR and HSR, respectively) compared with the late CD treatment (94 and $89 \%$ of LSR for MSR and HSR, respectively). In spring, the EC treatment had a reduced DHA compared with the LC treatment, where proportionally fewer animals were calved in each week in advance of the breeding season. The LC treatment received a similar daily area allocation to EC and consequently achieved an increased herbage allowance per cow per day in early lactation. However, EC had a lower total daily feed allowance compared with LC treatments, reflecting the important biological effect of a 16-d delay in mean $\mathrm{CD}$ on feed availability within a predominantly grass-based spring-calving feed system. Herbage nutritive value during the current experiment was similar to previously reported levels for Irish grazing experiments (Horan et al., 2005), and the seasonal trends in sward nutritive value were similar to that reported by Coleman et al. (2010). Increasing SR has been associated with an improvement in herbage nutritive value due to reduced postgrazing residual herbage mass and increases in the leaf content of the sward (Macdonald et al., 2008). The greater OM digestibility and CP of the higher SR treatments were previously observed by King and Stockdale (1980). Both Stakelum and Dillon (2007) and O'Donovan and Delaby (2008) previously reported increases in mid-summer sward nutritive value due to increased grazing intensity in spring and early summer, as lax grazing during this period results in increased stem and senesced material during subsequent rotations (Michell and Fulkerson, 1987; Lee et al., 2008). Calving date treatment had no effect on the nutritive value of the herbage, as CD paddocks within each SR were managed similarly and had the same PGRSH. Similarly, Garcia and Holmes (2005) reported no effect of calving systems on the chemical composition of the herbage grazed.

The greater milk, fat, protein, lactose, and MS yields per cow and increased BW and BCS achieved during the intake measurement periods in the LSR groups are consistent with previous experiments at similar SR (King and Stockdale, 1980; Horan et al., 2005; Macdonald et al., 2008), and are likely due to the greater energy supply because of increased herbage availability. We found no interaction between SR and CD for milk production in the current study. However, a significant interaction was evident for both BW and BCS due to the relatively increased $\mathrm{BW}$ and $\mathrm{BCS}$ of the late $\mathrm{CD}$ higher SR treatments. Dillon et al. (1995) also observed that delaying calving until March achieved a better alignment of dairy herd requirements, grass growth, and increased milk production from grazed grass and 
reduced the requirement for purchased supplements, particularly at higher SR. Similar to previous studies (Prendiville et al., 2009), the amount of milk produced for a given liveweight was used as an indicator of food efficiency within the current analysis. The results of this analysis indicate that as SR increases, total DMI per $100 \mathrm{~kg}$ of $\mathrm{BW}$ is reduced as a similar amount of energy is partitioned to body tissue, resulting in reduced energy availability for milk production and reduced MS production per $100 \mathrm{~kg}$ of BW. Similarly, Macdonald et al. (2001) previously observed that as individual animal DMI is reduced at higher SR and milk production per cow is reduced, an increasing proportion of the feed eaten is used for maintenance and pregnancy, thus reducing gross feed efficiency of milk production. The results of this study also indicate that the net feed efficiency (UFL of NEI; MS production per UFL available for production after maintenance) increases at higher $\mathrm{SR}$ and reflects the reduced utilization of energy for BW gain of animals at higher SR reported previously by McCarthy et al. (2012). These results are consistent with Mackle et al. (1996) and Coleman et al. (2010), who observed that food conversion efficiency was greatest in early lactation when animals were in negative EB.

The negative effect of increased SR on DHA, DMI, and estimated EB in early lactation is more pronounced in this analysis compared with previous studies within Irish grazing systems (Horan et al., 2005; Kennedy et al., 2006) and elsewhere (Leaver, 1985; Peyraud et al., 1996) and is indicative of the increased genetic merit of the cows, increased competition, and reduced availability of feed at higher SR, where supplementation did not increase as SR increased. The increase in DMI from spring to summer (up to 120 DIM), followed by a decline into late lactation, as reported here, is consistent with the DMI curves across lactation observed by Roseler et al. (1997) and Coleman et al. (2010). Increased SR is generally associated with an increase in herbage utilization (Hoden et al., 1991; Macdonald et al., 2008; McCarthy et al., 2013b) but also simultaneously leads to a reduction in DHA (Baudracco et al., 2010; McCarthy et al., 2011), resulting in reduced animal intake (Dillon, 2006; Leaver, 1985) and EB (Horan et al., 2005). The small differential in grass and total DMI between the LSR and MSR treatments was not surprising given that both systems received high grass DM allowances compared with the HSR group over the entire grazing season. Although increased SR reduced $\mathrm{BW}$ and BCS and resulted in more severe negative $\mathrm{EB}$ in early lactation, McCarthy et al. (2012) previously reported no significant effect of SR on reproductive performance based on a subset of data collected within this farm system study, albeit with limited numbers of animals in each treatment. Similar to Cutullic et al. (2011), these results indicate that, although reduced feed allowances result in reduced BCS, the reproductive capacity of the animal is not detrimentally affected as milk production is also reduced.

The effect of CD in early lactation was similar to that of SR, influencing the ratio of herbage supply to animal requirements during the highly influential early lactation phase. Later calving coincided with increased grass growth and feed availability during the spring and resulted in increased spring herbage allowances for all SR treatments and increased DMI and EB for the highly feed restricted MSR and HSR treatments. Calving date had no effect on any of the various measures of milk production efficiency. The effect of $\mathrm{S}$ on milk production, DMI, EB, and milk production efficiency within this study is consistent with similar previous studies (Horan et al., 2005; Coleman et al., 2009) and encompasses both the effect of season of year and the effect of lactation stage for these compact calving herds. The presence of significant interactions between SR and $\mathrm{CD}$ and between $\mathrm{SR}, \mathrm{CD}$, and $\mathrm{S}$ for DMI and $\mathrm{EB}$ indicates that the reduction in DMI and $\mathrm{EB}$ at higher SR may be reduced by delaying calving, particularly in spring. Based on a complete lactation multi-year evaluation of milk production effects of the current treatments, McCarthy et al. (2013a) observed that the interaction of SR and CD for milk production during the first 14 wk of lactation approached significance as the LSR treatment achieved similar milk production in both calving groups, whereas the LC treatment in the HSR produced more milk $(+159 \mathrm{~kg}), \mathrm{SCM}(+165$ $\mathrm{kg})$, and MS $(+13 \mathrm{~kg})$ per cow than the EC treatment. These results indicate that adjusting mean CD may be an effective strategy to align animal requirements and grass supply at increased SR in early lactation.

\section{Effect of Grazing and Animal Characteristics on Grass DMI}

Feeding of grazing ruminants is difficult to manage in practice because of the inability of farmers to accurately estimate nutrient intake from grazed grass (Delagarde et al., 2011). Grass allocation has traditionally been described in terms of average DHA, and previous studies have indicated a close relationship between DHA and DMI (Leaver, 1985; Peyraud et al., 1996). Peyraud et al. (1996) observed that the relationship between DHA and grass DMI was curvilinear, with a plateau reached at $33 \mathrm{~kg}$ of $\mathrm{DM} /$ cow per day. The relationship between average DHA and DMI observed in the current analysis (equation 1) is consistent with these previous studies and indicates that grass DMI at grazing increases by $0.25 \mathrm{~kg}$ per 1-kg increase in DHA. Similarly, Delagarde 
and O'Donovan (2005) observed an increase in grass DMI of $0.20 \mathrm{~kg}$ of DM per $\mathrm{kg}$ of DM increase in herbage allowance at similar DHA in a review of 7 published experiments. More recently, strong evidence has emerged demonstrating that individual animal characteristics such as age, BW, stage of lactation and gestation, and milk production potential also influence the feed intake capacity of the individual animal at grazing (van Arendonk et al., 1991; McEvoy et al., 2009; Faverdin et al., 2011; O'Neill et al., 2013); consequently, these authors have developed improved prediction equations for the relationship between DHA and DMI by incorporating such animal-specific characteristics. The results of the multiple regression analysis undertaken in this study indicate that the inclusion of parity, individual animal milk production potential, and $\mathrm{BW}$ (equation 2) is justified and can significantly improve the accuracy of prediction of nutrient intake from grazed grass. Similar to both Faverdin et al. (2011) and O'Neill et al. (2013), these results indicate that older dairy cattle of large BW or with increased genetic potential for milk production, by virtue of an increased grass DMI capacity, can achieve a greater grass DMI for any given group average DHA.

Delagarde et al. (2011) previously hypothesized that the grass DMI of the individual animal within a herd under rotational grazing is influenced first by the average DHA of the group, second by the intake capacity of the individual animal within the group, and third by the characteristics of other animals within the herd, as the limited area per cow per day leads to competition for feed. The results of the final multiple regression undertaken in this study (equation 3) support the hypothesis of Delagarde et al. (2011) and justify a new measure of herbage allowance, known here as the individual herbage allowance (IndHA). The high $\mathrm{R}^{2}$ and reduced mean square prediction error of IndHA reported here indicate that the DMI of the individual animal at grazing is mainly explained in the current experiment by 3 aspects: the traditional average daily herbage allowance of the group (DHA), the intake capacity of the individual animal, and finally the relative intake capacity of the animal within the competing group. The development of improved measures of herbage availability to more accurately predict the likely intake of the individual animal at grazing can improve decision support systems to improve animal performance at grazing. The results of this analysis indicate that such support systems must incorporate new measures of herbage availability to the individual animal that closely reflect grass DMI based on an increased knowledge of individual animal characteristic and the competitive interactions among the herd, in addition to the average supply of feed to the group.

\section{CONCLUSIONS}

The high SR tested in this study are above those used in commercial practice in milk production systems in Ireland and provide an insight into the productivity of such systems ahead of industry uptake. This study shows that in a grass-based system, individual animal milk production, BW, and BCS will be significantly reduced as SR increases because of a reduction in herbage availability and DMI to the individual animal. The presence of an $\mathrm{SR} \times \mathrm{CD} \times \mathrm{S}$ interaction for grass and total DMI and EB indicates that the reduction in individual animal intake and milk production performance in spring at higher SR can be effectively reduced by delaying the herd mean calving date. A retrospective analysis of the main factors influencing DMI at grazing emphasizes the appropriateness of a new measure of herbage allowance, known here as the individual herbage allowance (IndHA), which encompasses the main factors restricting DMI of dairy cattle in rotational grazing systems; namely, the average DHA of the group, the intake capacity of the individual animal within the group, and the relative intake capacity of the animal within the competing herd.

\section{ACKNOWLEDGMENTS}

The authors thank M. Feeney and F. Flynn (both from Teagasc Moorepark, Fermoy, Co. Cork, Ireland) for their technical assistance. We also thank the staff of Curtins Farm, Moorepark, for their co-operation, care and management of the experimental cows.

\section{REFERENCES}

Allen, V. G., C. Batello, E. J. Berretta, J. Hodgson, M. Kothmann, X. Li, J. McIvor, J. Milne, C. Morris, A. Peeters, and M. Sanerson., and The Forage and Grazing Terminology Committee. 2011. An international terminology for grazing lands and grazing animals. Grass Forage Sci. 66:2-28.

Baudracco, J., N. Lopez-Villalobos, C. W. Holmes, and K. A. Macdonald. 2010. Effects of stocking rate, supplementation, genetic strain and their interactions on grazing dairy systems: A review. N.Z. J. Agric. Res. 53:109-133.

Coleman, J., K. M. Pierce, D. P. Berry, A. Brennan, and B. Horan. 2009. The influence of genetic selection and feed system on the reproductive performance of spring-calving dairy cows within future pasture-based production systems. J. Dairy Sci. 92:5258-5269.

Coleman, J., K. M. Pierce, D. P. Berry, A. Brennan, and B. Horan. 2010. Increasing milk solids production across lactation through genetic selection and intensive pasture-based feed system. J. Dairy Sci. 93:4302-4317.

Cutullic, E., L. Delaby, Y. Gallard, and C. Disenhaus. 2011. Dairy cows' reproductive response to feeding level differs according to the reproductive stage and the breed. Animal 5:731-740.

DAFM (Department of Agriculture, Food and the Marine). 2010. Food Harvest 2020. Department of Agriculture, Fisheries, and Food, Dublin, Ireland.

Dalley, D. E., J. R. Roche, C. Grainger, and P. J. Moate. 1999. Dry matter intake, nutrient selection and milk production of dairy cows 
grazing rainfed perennial pastures at different herbage allowances in spring. Aust. J. Exp. Agric. 39:923-931.

Delaby, L., and J. L. Peyraud. 1998. Effet d'une réduction simultanée de la fertilisation azotée et du chargement sur les performances des vaches laitières et la valorisation du pâturage (Effect of a simultaneous reduction in nitrogen fertilization and stocking rate on the performance of dairy cows and pasture utilization). Ann. Zootech. 47:17-39.

Delagarde, R., P. Faverdin, C. Baratte, and J. L. Peyraud. 2011. GrazeIn: A model of herbage intake and milk production for grazing dairy cows. 2. Prediction of intake under rotational and continuously stocked grazing management. Grass Forage Sci. 66:45-60.

Delagarde, R., and M. O'Donovan. 2005. Modelling of herbage intake and milk production by grazing dairy cows. Pages 89-104 in Utilisation of Grazed Grass in Temperate Animal Systems: Proceedings of a Satellite Workshop of the XXth International Grassland Congress, Cork, Ireland. J. J. Murphy, ed. Wageningen Academic Publishers, Wageningen, the Netherlands.

Dillon, P. 2006. Achieving high dry-matter intake from pasture with grazing dairy cows. Pages 1-26 in Fresh Herbage for Dairy Cattle. A. Elgersma, J. Dijkstra, and S. Tamminga, ed. Wageningen Academic Publishers, the Netherlands.

Dillon, P., S. Crosse, G. Stakelum, and F. Flynn. 1995. The effect of calving date and stocking rate on the performance of spring calving dairy cows. Grass Forage Sci. 50:286-299.

Dillon, P., T. Hennessy, L. Shalloo, F. Thorne, and B. Horan. 2008. Future outlook for the Irish dairy industry: A study of international competitiveness, influence of international trade reform and requirement for change. Int. J. Dairy Technol. 61:16-29.

Dillon, P., and G. Stakelum. 1989. Herbage and dosed alkanes as a grass measurement technique for dairy cows. Irish J. Agric. Sci. Res. 28:104. (Abstr.)

Edmonson, A. J., I. J. Lean, L. D. Weaver, T. Farver, and G. Webster. 1989. A body condition scoring chart for Holstein dairy cows. J. Dairy Sci. 72:68-78.

Farina, S. R., S. C. Garcia, W. J. Fulkerson, and I. M. Barchia. 2011. Pasture-based dairy farm systems increasing milk production through stocking rate or milk yield per cow: Pasture and animal responses. Grass Forage Sci. 66:316-332.

Faverdin, P., R. Delagarde, C. Baratte, and J. L. Peyraud. 2011. GrazeIn: A model of herbage intake and milk production for grazing dairy cows. 1. Prediction of intake capacity, voluntary intake and milk production during lactation. Grass Forage Sci. 66:29-44.

Garcia, S. C., and C. W. Holmes. 2005. Seasonality of calving in pasture-based dairy systems: Its effects on herbage production, utilization and dry matter intake. Aust. J. Exp. Agric. 45:1-9.

Greenhalgh, J. F. D., G. W. Reid, J. N. Aitken, and E. Florence. 1966. The effects of grazing intensity on herbage consumption and animal production 1. Short term effects in strip-grazed dairy cows. J. Agric. Sci. (Camb.) 67:13-23.

Hoden, A., J. L. Peyraud, A. Muller, L. Delaby, and P. Faverdin. 1991. Simplified rotational grazing management of dairy cows: Effects of rates of stocking and concentrate. J. Agric. Sci. (Camb.) 116:417-428.

Holmes, C. W., G. F. Wilson, D. D. S. Mackenzie, D. S. Flux, I. M. Brookes, and A. W. F. Davey. 2002. Feeding the herd. Pages 33-89 in Milk Production from Pasture. 3rd ed. Butterworths, Wellington, New Zealand.

Horan, B., P. Dillon, P. Faverdin, L. Delaby, F. Buckley, and M. Rath. 2005. The interaction of strain of Holstein-Friesian cows and pasture-based feed systems on milk yield, body weight, and body condition score. J. Dairy Sci. 88:1231-1243.

Horan, B., J. F. Mee, M. Rath, P. O'Connor, and P. Dillon. 2004. The effect of strain of Holstein-Friesian cow and feed system on reproductive performance in seasonal-calving milk production systems. Anim. Sci. 79:453-468.

Kennedy, E., M. McEvoy, J. P. Murphy, and M. O'Donovan. 2009. Effect of restricted access time to pasture on dairy cow milk production, grazing behavior, and dry matter intake. J. Dairy Sci. $92: 168-176$.
Kennedy, E., M. O'Donovan, J. P. Murphy, F. P. O'Mara, and L. Delaby. 2006. The effect of initial spring grazing date and subsequent stocking rate on the grazing management, grass dry matter intake and milk production of dairy cows in summer. Grass Forage Sci. $61: 375-384$

King, K. R., and C. R. Stockdale. 1980. The effects of stocking rate and nitrogen fertilizer on the productivity of irrigated perennial grazed by dairy cows. 1. Pasture production, utilization and composition. Aust. J. Exp. Agric. Anim. Husb. 20:537-542.

Le Du, Y. L. P., J. Combellas, J. Hodgson, and R. D. Baker. 1979. Herbage intake and milk production by grazing dairy cows. 2 . The effects of level of winter feeding and daily herbage allowance. Grass Forage Sci. 34:249-260.

Leaver, J. D. 1985. Milk production from grazed temperate grassland. J. Dairy Res. 52:313-344.

Lee, J. M., D. J. Donaghy, and J. R. Roche. 2008. Effect of defoliation severity on regrowth and nutritive value of perennial ryegrass dominant swards. Agron. J. 100:308-314.

Lips, M., and P. Reider. 2005. Abolition of raw milk quota in the European Union: A CGE analysis at the member country level. J. Agric. Econ. 56:1-17.

Lopez-Villalobos, N., D. P. Berry, B. Horan, F. Buckley, J. Kennedy, M. O'Donovan, L. Shalloo, and P. Dillon. 2008. Genetics of residual feed intake in Irish grazing dairy cows. Proc. N.Z. Soc. Anim. Prod. 68:97-100.

Macdonald, K. A., J. W. Penno, J. A. S. Lancaster, and J. R. Roche. 2008. Effect of stocking rate on pasture production, milk production, and reproduction of dairy cows in pasture-based systems. J. Dairy Sci. 91:2151-2163.

Macdonald, K. A., J. W. Penno, P. K. Nicholas, J. A. Lile, M. Coulter, and J. A. S. Lancaster. 2001. Farm systems-Impact of stocking rate on dairy farm efficiency. Proc. N.Z. Grassl. Assoc. 63:223227

Mackle, T. R., C. R. Parr, G. K. Stakelum, A. M. Bryant, and K. L. MacMillan. 1996. Feed conversion efficiency, daily pasture intake, and milk production of primiparous Friesian and Jersey cows calved at two different live weights. N. Z. J. Agric. Res. 39:357-370.

Mayes, R. W., C. S. Lamb, and P. A. Colgrove. 1986. The use of dosed n-alkanes as markers for the determination of herbage intake. J. Agric. Sci. 107:161-170.

McCarthy, B., L. Delaby, K. M. Pierce, A. Brennan, and B. Horan. 2013a. The effect of stocking rate and calving date on milk production of Holstein-Friesian dairy cows. Livest. Sci. 153:123-134.

McCarthy, B., L. Delaby, K. M. Pierce, F. Journot, and B. Horan. 2011. Meta-analysis of the impact of stocking rate on the productivity of pasture-based milk production systems. Animal 5:784794.

McCarthy, B., K. M. Pierce, L. Delaby, A. Brennan, C. Fleming, and B. Horan. 2013b. The effect of stocking rate and calving date on grass production, utilization and nutritive value of the sward during the grazing season. Grass Forage Sci. 68:364-377. http:// dx.doi.org/10.1111/j.1365-2494.2012.00904.x.

McCarthy, B., K. M. Pierce, L. Delaby, A. Brennan, and B. Horan. 2012. The effect of stocking rate and calving date on reproductive performance, body state, and metabolic and health parameters of Holstein-Friesian dairy cows. J. Dairy Sci. 95:1337-1348.

McCarthy, S., B. Horan, P. Dillon, P. O'Connor, M. Rath, and L. Shalloo. 2007. Economic comparison of divergent strains of Holstein-Friesian cows in various pasture-based production systems. J. Dairy Sci. 90:1493-1505.

McEvoy, M., M. O'Donovan, E. Kennedy, J. P. Murphy, L. Delaby, and T. M. Boland. 2009. Effect of pregrazing herbage mass and pasture allowance on the lactation performance of Holstein-Friesian dairy cows. J. Dairy Sci. 92:414-422.

McMeekan, C. P., and M. J. Walsh. 1963. The inter-relationships of grazing method and stocking rate in the efficiency of pasture utilization by dairy cattle. J. Agric. Sci. (Camb.) 61:147-166. 
Michell, P., and W. J. Fulkerson. 1987. Effect of grazing intensity in spring on pasture growth, composition and digestibility, and on milk production by dairy cows. Aust. J. Exp. Agric. 27:35-40.

National Farm Survey. 2009. National Farm Survey Data, Teagasc, Oak Park, Carlow, Ireland.

O'Donnell, S., L. Shalloo, A. M. Butler, and B. Horan. 2008. A survey analysis of opportunities and limitations of Irish dairy farmers. J. Farm Manage. 13:1-15.

O'Donovan, M., and L. Delaby. 2008. Sward characteristics, grass dry matter intake and milk production performance is affected by timing of spring grazing and subsequent stocking rate. Livest. Sci. $115: 158-168$

O'Mara, F. 2000. A Net Energy System for Cattle and Sheep. Version 1.2. Univ. Coll. Dublin, Ireland.

O'Neill, B. F., E. Lewis, M. Donovan, L. Shalloo, N. Galvin, F. J. Mulligan, T. M. Boland, and R. Delagarde. 2013. Evaluation of the GrazeIn model of grass dry matter intake and milk production prediction for dairy cows in temperate grass-based production systems. 2: Animal characteristics. J. Br. Grassl. Soc. 68:524-536 http://dx.doi.org/10.1111/gfs.12022.

Patton, D., L. Shalloo, K. M. Pierce, and B. Horan. 2012. A biological and economic comparison of 2 pasture-based production systems on a wetland drumlin soil in the northern region of Ireland. J. Dairy Sci. 95:484-495

Penno, J. W., K. A. Macdonald, and A. M. Bryant. 1996. The economics of the No. 2 Dairy systems. Proc. Ruakara Farmers Conf. 48:11-19. DairyNZ, Hamilton, New Zealand.

Peyraud, J. L., E. A. Comeron, M. H. Wade, and G. Lemaire. 1996. The effect of daily herbage allowance, herbage mass and animal factors upon herbage intake by grazing dairy cows. Ann. Zootech. 45:201-217.

Prendiville, R., K. M. Pierce, and F. Buckley. 2009. An evaluation of production efficiencies among lactating Holstein-Friesian, Jersey, and Jersey $\times$ Holstein-Friesian cows at pasture. J. Dairy Sci. 92:6176-6185.

Prendiville, R., L. Shalloo, K. M. Pierce, and F. Buckley. 2011. Comparative performance and economic appraisal of Holstein-Friesian Jersey and Jersey $\times$ Holstein cows under seasonal pasture-based management. Ir. J. Agric. Food Res. 50:123-140.

Roseler, D. K., D. G. Fox, L. E. Chase, A. N. Pell, and W. C. Stone. 1997. Development and evaluation of equations for prediction of feed intake for lactating Holstein dairy cows. J. Dairy Sci. 80:878-893.

Stakelum, G., and P. Dillon. 2007. The effect of grazing pressure on rotationally grazed pastures in spring/early summer on subsequent sward characteristics. Ir. J. Agric. Food Res. 46:15-28.

SAS Institute. 2006. User's Guide: Statistics. Version 9.1. SAS Institute Inc., Cary, NC.

Tyrrell, H. F. and J. T. Reid. 1965. Prediction of the energy value of cows' milk. J. Dairy Sci. 48:1215-1223.

Van Arendonk, J. A. M., G. J. Nieuwhof, H. Vos, and S. Korver. 1991. Genetic aspects of feed intake and efficiency in lactating dairy heifers. Livest. Prod. Sci. 29:263-275.

Wims, C. M., M. H. Deighton, E. Lewis, B. O'Loughlin, L. Delaby, T. M. Boland, and M. O'Donovan. 2010. Effect of pregrazing herbage mass on methane production, dry matter intake, and milk production of grazing dairy cows during the mid-season period. J. Dairy Sci. 93:4976-4985. 